\title{
Longitudinal measurements of $17 \alpha$-hydroxyprogesterone in premature infants during the first three months of life
}

\author{
N Linder, N Davidovitch, A Kogan, A Barzilai, J Kuint, R Mazkeret, J Sack
}

\begin{abstract}
Aims-To determine normal concentrations of $17 \alpha$-hydroxyprogesterone (17OHP) for premature infants.

Methods-170HP was measured in 66 consecutive premature infants once a week during the first month, and once every two weeks thereafter, until the age of 3 months. The $170 H P$ values in 100 full term healthy neonates on the third day of life served as controls. Blood was sampled on filter paper using a neonatal radioimmunoassay kit. Findings were correlated with gestational age, birthweight, mode of delivery, Apgar scores, presence of respiratory distress syndrome and intake of maternal steroids.
\end{abstract}

Results-Mean 17OHP was raised at 7 days of age $(138.9,46.3,53.3,29.9 \mathrm{nmol} / 1$, respectively, for infants whose gestational age was under 29 weeks, 29 to 30 weeks, 31 to 32 weeks, and 33 weeks and above). It fell sharply in the first two weeks after which it gradually decreased further, reaching $32.7,23.6,16.9$, and $13.0 \mathrm{nmol} / 1$, respectively, by the age of 90 days. The mean (SEM) 17OHP concentration in full term infants on day 3 of life was $17.8(8.9)$ nmol/1. These values were independent of the presence and severity of respiratory distress syndrome and of prenatal maternal steroids.

Conclusions-The increased 17OHP concentrations found at birth fell to those found in term infants during the first three months of life in infants over 31 weeks of gestation. Postconceptional age is the most important factor determining 17OHP concentration.

(Arch Dis Child Fetal Neonatal Ed 1999;81:F175-F178)

Keywords: 17 $\alpha$-hydroxyprogesterone; postconceptional age; congenital adrenal hyperplasia; steroids

Congenital adrenal hyperplasia $(\mathrm{CAH})$ is a family of recessive inherited disorders of adrenal steroid hormone origin, caused in $90-95 \%$ of cases, by 21 -hydroxylase deficiency. ${ }^{1} \mathrm{CAH}$ is suspected in newborn girls with ambiguous genitalia, phenotypic boys with bilateral cryptorchidism, older boys with progressive virilisation and in neonates with acute adrenal insufficiency. ${ }^{2-4}$ The diagnosis is readily confirmed by increased $17 \alpha$-hydroxyprogesterone (17OHP) concentrations.

Over the past two decades neonatal (age 2-5 days) screening programmes for high $17 \mathrm{OHP}$ values using heel blood spots have been instituted in several regions and countries. ${ }^{15-7}$ In Israel a nationwide random screening programme revealed a high incidence of $\mathrm{CAH}$ in the Arab population, which prompted a second programme for neonates in northern Israel. ${ }^{8}$ One of the major problems encountered in our programme and in others is the high incidence of false positive results in preterm infants. $.^{2-5} 8-13$

This study aimed to determine normal concentrations of 17OHP for premature infants during the first three months of life and to correlate these with postconceptional age, birthweight, incidence and severity of respiratory distress syndrome, and antenatal use of steroids.

\section{Methods}

The study was conducted in the neonatal intensive care unit of the Chaim Sheba Medical Center. Sixty six consecutive premature infants (gestational age $<35$ weeks, birthweight $<2000$ g), born between January and August 1994, were included. One hundred term healthy infants (gestational age $>37$ weeks, birthweight $>2500 \mathrm{~g}$ ) served as controls. The study was approved by the hospital's human rights committee, and informed consent was obtained from the parents of each participant. The clinical characteristics of the patients are shown in table 1.170HP was correlated with sex, Apgar score, mode of delivery (vaginal or caesarean) the need for blood transfusions, presence of neonatal sepsis, incidence and severity of respiratory distress syndromemild, need for oxygen; moderate, need for mechanical ventilation for up to 5 days; severe, need for mechanical ventilation $>5$ days-or prenatal treatment with dexamethasone for fetal lung immaturity.

In the preterm group blood was sampled on filter paper during the first 24 hours, then once a week during the first 28 days, and thereafter every two weeks until 60 days of age, and again at 90 days. In the term group blood samples were obtained on the third day of life. $17 \mathrm{OHP}$ concentrations were measured by radioimmunoassay (Diagnostic Products Corporation, Los Angeles, CA) in the National Unit for Congenital Hypothyroidism and Screening Program for 21-hydroxylase deficiency. ${ }^{8}$

Blood spot 17-OHP concentrations were determined using a solid phase ${ }^{125} \mathrm{I}$ radioimmunoassay with the Coat-A-Count Neonatal 17-alpha-OH Progesterone kit (Diagnostic Products Corporation, Los Angeles, CA). 
Table 1 Clinical characteristics of patients $(n=66)$

\begin{tabular}{lll}
\hline & Full term $(n=100)$ & Preterm $(n=66)$ \\
\hline Gestational age (weeks) (mean (SD)) & $39.2(2.7)$ & $31.8(2.1)$ \\
Birth weight (g) (mean (SD)) & $3.100(448)$ & $1488(291)$ \\
Male/female & $47 \% / 53 \%$ & $45.5 \% / 54.5 \%$ \\
Type of delivery:vaginal/caesarean section & $92 \% / 8 \%$ & $28 \% / 72 \%$ \\
Apgar score 1 minute (mean (SD)) & 9 & $7.4(2.4)$ \\
Apgar score 5 minutes (mean (SD)) & 10 & $8.9(1.2)$ \\
Single/twin/triplet & $100 \%$ singleton & $50 \% / 28.8 \% / 21.2 \%$ \\
Maternal steroids (\%) & None & $41(60.2 \%)$ \\
Respiratory distress syndrome & None & $24(35 \%)$ \\
& & $($ mild: 6, moderate: 11, severe: 7$)$ \\
Blood transfusions & None & $10(15.2 \%)$ \\
Sepsis & None & $3(4.4 \%)$ \\
\hline
\end{tabular}

The procedure is based on a polyclonal (rabbit) antibody and designed for use with blood spot samples. ${ }^{125}$ I-labelled $17 \mathrm{OHP}$ competes for a fixed time with 17OHP in the patient sample for antibody sites. As the antibody is immobilised to the wall of a tube, decanting suffices to terminate the competition and to isolate the antibody bound fraction of the radiolabelled 17OHP. Counting the tube in a gamma counter then yields a number which converts, by way of a calibration curve, to a measure of the $17 \mathrm{OHP}$ in the patient sample.

The sensitivity of the $17 \mathrm{OHP}$ assay is 0.8 $\mathrm{nmol} / \mathrm{l}$ and the intra- and interassay coefficients of variation $(\mathrm{CV})$ are $6 \%$ and $0 \%$, respectively. Cross reactivity with other naturally occurring steroids or therapeutic drugs is extremely low, maximally to $17 \mathrm{OHP}(3.5 \%)$ and to 11 deoxycortisol $(0.8 \%)$.

Statistical analysis was performed using BMDP Statistical Software. ${ }^{14}$ One and two way analysis of variance and covariance with repeated measures, Fisher's exact test, Pearson's $\chi^{2}$ test, paired $t$ test and regression analysis were used, as appropriate. Correlations were performed using Student's linear regression analysis.

\section{Results}

Mean 17OHP concentrations by day 7 of life were higher in the premature infants than in full term infants on day 3 of life $(p<0.01)$. Concentrations sharply declined in the first two weeks, and then continued to decrease more gradually. By the age of 3 months, the average $17 \mathrm{OHP}$ concentrations for preterm infants over 29 weeks decreased to those of full term infants at the age of 3 days. However, for

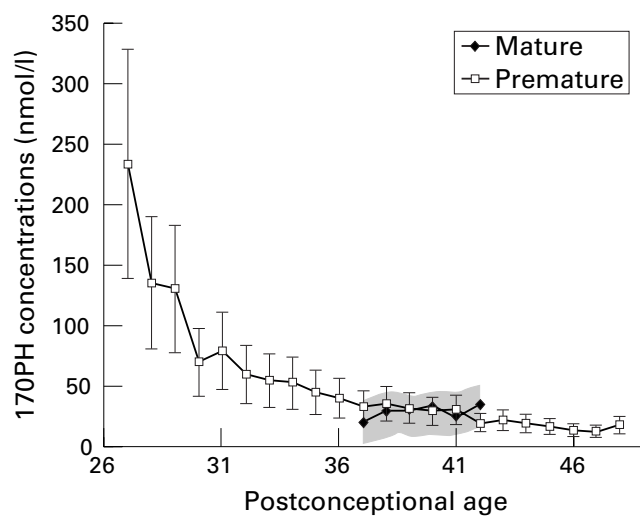

Figure 1 17OHP concentrations according to postconceptional age.
Table $217 \mathrm{OHP}$ concentrations (nmol/l) in preterm infants according to birthweight groups

\begin{tabular}{|c|c|c|c|}
\hline \multirow[b]{2}{*}{ Age (days) } & \multicolumn{3}{|c|}{ Birthweight (g) Mean (SD) } \\
\hline & $\begin{array}{l}500-1000 \\
n=6\end{array}$ & $\begin{array}{l}1001-1500 \\
n=24\end{array}$ & $\begin{array}{l}1501-2000 \\
n=36\end{array}$ \\
\hline 1 & $249.6(143.8)$ & $101.9(55.5)$ & $86.4(36.7)$ \\
\hline 7 & $171.3(71.4)$ & $51.6(35.1)$ & $47.4(28.0)$ \\
\hline 14 & $67.0(33.0)$ & $43.2(23.7)$ & 38.7 (13.5) \\
\hline 21 & $44.2(13.1)$ & $37.5(15.4)$ & $42.5(18.5)$ \\
\hline 28 & $41.6(13.3)$ & $46.1(18.7)$ & $45.7(21.0)$ \\
\hline 45 & $29.6(6.9)$ & $40.4(12.4)$ & $33.1(17.0)$ \\
\hline 60 & $34.4(30.2)$ & $28.8(8.2)$ & $22.5(14.0)$ \\
\hline 90 & $31.8(2.1)$ & $20.9(12.5)$ & $15.9(6.3)$ \\
\hline
\end{tabular}

infants below 29 weeks, the concentration at 3 months was almost double that of full term infants $(p<0.05)$. Only those who were born at more than 33 weeks of gestation achieved term values by 60 days of age. During the first two weeks of life, 17OHP concentration was inversely correlated with postconceptional age and birthweight. Analysis of variance and covariance was significant for both factors, but stronger for postconceptional age $(p<0.0001)$ (fig 1) than for birthweight (table 2) $(p<0.004)$. The normalisation of 17OHP concentrations was slower in the smaller and younger infants (500-1000 g; 26-28 weeks, respectively). Analysis of variance and covariance showed no relation between $17 \mathrm{OHP}$ concentrations and sex, Apgar score, mode of delivery, need for blood transfusions, presence of neonatal sepsis, incidence and severity of respiratory distress syndrome, or prenatal treatment with dexamethasone for fetal lung immaturity. Regression analysis revealed a significant influence for both birthweight and postconceptional age on $17 \mathrm{OHP}$ concentrations $\left(\mathrm{R}^{2}=0.058, \mathrm{~F}=11.9, \mathrm{p}<0.00001\right)$.

The higher rate of respiratory distress syndrome in the young and low birthweight premature infants gave the impression that these infants have higher $17 \mathrm{OHP}$ concentrations. However, analysis of variance and covariance showed that it was gestational age rather than the lung disorder which was the significant factor.

\section{Discussion}

Although pilot programmes for infant screening for high $17 \mathrm{OHP}$ concentrations began more than 15 years ago, only 23 are used today in 10 countries. This is partly due to the high financial outlay required, but also to the psychological cost of the high rate of false positive results, ${ }^{15}$ particularly in preterm, small for gestational age, and sick infants under stress. ${ }^{511}$ The latter may be attributed to the following: differences in the activity of enzymes in the glucocorticoid pathway which may be developmentally regulated to increase with advancing postconceptional age; decreased metabolic clearance of 17OHP due to immature hepatic function; physiological pituitary adrenal stress response; and cross reaction with conjugated steroids in the premature neonate's serum. ${ }^{410} 12$ For these reasons, higher recall values for preterm infants have since been established in the various screening programmes (table 3 ). 
Table 3 17a-hydroxyprogesterone concentrations in preterm infants: review of published findings

\begin{tabular}{|c|c|c|c|c|c|c|c|c|}
\hline Author Year & No of preterm infants & Time of collection & \multicolumn{5}{|c|}{$17 O H P(n m o l / l)$} & Remarks \\
\hline Cacciari et $a l^{17} 1983$ & $\begin{array}{l}\text { Total } 41299 \\
\text { preterm } 3935\end{array}$ & Days $1-15$ & \multicolumn{5}{|c|}{$\begin{array}{l}\text { Peak } 13 \mathrm{pg} / \text { disk } \\
\quad \text { range } 13-5 \mathrm{pg} / \text { disk }\end{array}$} & $\begin{array}{l}\text { Infant maturity and day of collection } \\
\text { affect values }\end{array}$ \\
\hline Wallace et $a l^{9} 1985$ & $\begin{array}{l}376 \text { (direct method) } \\
118 \text { (extraction method) }\end{array}$ & Second week after birth & \multicolumn{5}{|c|}{$\begin{array}{l}\text { Direct: median } 31 \mathrm{nmol} / 1 \\
\quad \text { extraction: median } 13.5 \text { range } 0-75 \\
\mathrm{nmol} / 1\end{array}$} & Results were lower in extraction assay \\
\hline Berry et $a l^{12} 1986$ & 32 & Days $3,8,14$ & \multicolumn{5}{|c|}{$\begin{array}{l}\text { Peak } 130 \mathrm{nmol} / 1(\mathrm{day}=3) \\
\text { range } 20-80 \mathrm{nmol} / 1\end{array}$} & $\begin{array}{l}\text { Upper limit: term infants-20 nmol/1 } \\
\text { preterm-200 nmol/1 }\end{array}$ \\
\hline Laresson et $a l^{10} 1988$ & $\begin{array}{l}\text { Total } 22400 \\
\text { (preterm }+ \text { full term) }\end{array}$ & $\begin{array}{l}\text { After } 72 \mathrm{~h} \text { (medain } 5 \\
\text { days) }\end{array}$ & \multicolumn{5}{|c|}{$\begin{array}{l}\mathrm{n}=201 \rightarrow 100 \mathrm{nmol} / 1 \\
\mathrm{n}=13->400 \mathrm{nmol} / 1\end{array}$} & Correlation with gestational age \\
\hline Thompson et al 1989 & $89(<2500 \mathrm{~g})$ & Days $1-24$ & \multicolumn{5}{|c|}{$\mathrm{n}=11->30 \mathrm{nmol} / 1$} & $\begin{array}{l}\text { Day of collection did not influence } \\
\text { results }\end{array}$ \\
\hline Lee $e t a l^{11} 1989$ & 22 (13 healthy, 9 sick) & Days $2-5$ & \multicolumn{5}{|c|}{$\begin{array}{l}\text { Healthy } 28.5(6.2) \mathrm{nmol} / 1 \\
\text { mean }(\mathrm{SD}) \text { sick } 42.2(7.2) \mathrm{nmol} / 1\end{array}$} & $\begin{array}{l}\text { Concentrations are higher in sick } \\
\text { preterm infants }\end{array}$ \\
\hline Knudtzon et al ${ }^{17} 1991$ & 26 & Days 3-17 (mean 7.7 ) & \multicolumn{5}{|c|}{ Mean (SD) $53.3(6.3) \mathrm{nmol} / 1$} & $\begin{array}{l}\text { Negative correlation with gestational } \\
\text { age and birth weight }\end{array}$ \\
\hline Ohkubo et al ${ }^{13} 1992$ & 836 & Days 3 to 96 & \multicolumn{5}{|c|}{$\begin{array}{l}<29 \mathrm{w}-2.0(1.39) \mathrm{nmol} / 1 \\
30-34 \mathrm{w}-1.3(0.85) \mathrm{nmol} / 1 \\
35-36 \mathrm{w}-0.82(0.85) \mathrm{nmol} / 1 \\
\text { (log values) }\end{array}$} & ELISA \\
\hline Hingre et $a l^{18} 1994$ & $25(<1250 \mathrm{~g})$ & Day 4 & \multicolumn{5}{|c|}{ Mean $(\mathrm{SD})=11.4(11.1) \mathrm{nmol} / 1$} & $\begin{array}{l}\text { High concentrations in very low } \\
\text { birthweight infants }\end{array}$ \\
\hline Al Saedi et $a l^{4} 1995$ & 39 healthy $<31$ weeks & $\begin{array}{l}\text { Once a week until age } \\
37 \text { weeks }\end{array}$ & \multicolumn{5}{|c|}{$\begin{array}{l}\text { Mean }(\mathrm{SD})=11.4(11.1) \mathrm{nmol} / 1 \\
\quad \text { range } 1.4-82.5 \mathrm{nmol} / 1\end{array}$} & $\begin{array}{l}\text { Predicted 17OHP concentrations: } \\
9.4-13 \text { - initial } \\
5.2-5.3-35 \text { to } 56 \text { days of age }\end{array}$ \\
\hline Allen et $a l^{15} 1997$ & 149684 & At time of discharge & \multicolumn{5}{|c|}{$\begin{array}{l}\text { Multitiered reporting scheme: } \\
1299 \mathrm{~g}-499.3 \mathrm{nmol} / 1 \\
1300-1699 \mathrm{~g}-408.5 \mathrm{nmol} / 1 \\
1700-2200 \mathrm{~g}-272.3 \mathrm{nmol} / 1 \\
>2200 \mathrm{~g}-121.0 \mathrm{nmol} / 1\end{array}$} & $\begin{array}{l}\text { Weight adjusted criteria reduced the } \\
\text { false positive results without } \\
\text { diminishing sensitivity }\end{array}$ \\
\hline \multirow{10}{*}{$\begin{array}{r}\text { Linder et al } 1999 \\
\text { (present study) }\end{array}$} & \multirow[t]{10}{*}{66} & \multirow{10}{*}{$\begin{array}{l}\text { Once a week during the } \\
\text { first month and then } \\
\text { every two weeks until } \\
\text { age } 3 \text { months }\end{array}$} & \multicolumn{5}{|c|}{$17 \mathrm{OHP}(\mathrm{nmol} / \mathrm{l})$} & $17 \mathrm{OHP}$ concentrations decline to full \\
\hline & & & Day & & $\begin{array}{l}29-30 \\
\text { week }\end{array}$ & $\begin{array}{l}31-32 \\
\text { week }\end{array}$ & $\begin{array}{l}>33 \\
\text { week }\end{array}$ & $\begin{array}{l}\text { term concentrations during the } \\
\text { first three months of life. }\end{array}$ \\
\hline & & & 1 & 179. & & 99.6 & 78.1 & Birthweight and gestational age \\
\hline & & & 7 & 138. & 46.3 & 53.3 & 29.9 & affect level \\
\hline & & & 14 & 63.2 & 40.2 & 42.9 & 29.7 & \\
\hline & & & 21 & 45.1 & 40.2 & 44.3 & 31.2 & \\
\hline & & & 28 & 42.1 & 48.7 & 48.1 & 32.1 & \\
\hline & & & 45 & 37.5 & 35.4 & 35.4 & 29.7 & \\
\hline & & & 60 & 35.0 & 26.9 & 25.1 & 17.8 & \\
\hline & & & 90 & 32.7 & 23.6 & 16.9 & 13.0 & \\
\hline
\end{tabular}

Our results confirm that normal $17 \mathrm{OHP}$ values for preterm infants are inversely correlated with postconceptional age and birthweight ${ }^{11-13} 16$

Contrary to Thompson et $a l,{ }^{3}$ who reported that age at the time of specimen collection had no effect on 17OHP concentrations in infants weighing under $2500 \mathrm{~g}$ at birth, we found that they sharply declined in the first two weeks of life and thereafter gradually reached full term values within the first three months of life. This phenomenon was accentuated in very young and low birthweight infants.

Al Saedi et $a l^{4}$ were the first to describe sequential sampling of $17 \mathrm{OHP}$ concentrations in preterm infants, performed weekly until 37 weeks of age. However, their mean concentrations were lower than those found in this study. Normal $170 \mathrm{HP}$ concentrations vary considerably, as noted in the various screening programmes; this reflects differences in the assay used (RIA, ELISA, FIA), antibody specificity, and the thickness of the blood spot. ${ }^{5}$ Mean $17 \mathrm{OHP}$ concentrations were not affected by the incidence of caesarean section, low Apgar scores, incidence and severity of respiratory distress syndrome, or maternal use of steroids. Gestational age had a greater effect on $17 \mathrm{OHP}$ concentrations than birthweight. This contrasts with the findings of Cacciari et $a l,{ }^{16}$ who found that birthweight was more significant than gestational age in determining $17 \mathrm{OHP}$ concentration in infants weighing under $2500 \mathrm{~g}$.
Recently, Allen et al ${ }^{15}$ suggested a four tiered weight adjusted threshold for $17 \mathrm{OHP}$. This reduced the number of false positive results, particularly among low birthweight infants, without diminishing the sensitivity of the test. Birthweight was chosen for categorisation because it was thought that the birthweight data supplied on the newborn screening form were more reliable and accurate than those on gestational age. Their criteria, however, did not take into account the day of specimen collection, an important variable in low birthweight babies.

In conclusion, increased $17 \mathrm{OHP}$ concentrations in premature infants may lead to a misdiagnosis of congenital adrenal hyperplasia. Notably, 17OHP concentrations in premature infants are independent of maternal glucocorticoid treatment, and the incidence and severity of respiratory distress syndrome, and will normally reach full term values within the first three months of life.

We are grateful to Mrs Ilsa Katz for her support, Mrs Pearl Lilos of the Department of Statistics, Tel Aviv University, for performing the data analysis, and Mrs Ora Amado and Mrs Judith Bruck of the Central Endocrinology Laboratory for their excellent technical assistance.

1 New MI. Steroid 21-hydroxylase deficiency (congenital adrenal hyperplasia). Am $\mathcal{F}$ Med 1995; 98(suppl 1A):2S$8 \mathrm{~S}$.

2 Wilson JD, Foster DW, eds. Williams Textbook of Endocrinology. 8th edn. Philadelphia: WB Saunders, 1992:907-12.

3 Thompson R, Seargant L, Winter JSD. Screening for congenital adrenal hyperplasia: Distribution of $17 \alpha$ hydroxyprogesterone concentrations in neonatal blood spot specimens. F Pediatr 1989;114:400-4. 
4 Al Saedi S, Dean H, Dent W, Stockl E, Cronin C. Screening for congenital adrenal hyperplasia: The Delfia screening test test overestimates serum 17-hydroxyprogesterone in

preterm infants. Pediatrics 1996;97:100-2.

Pang S, Wallace MA, Hoffman L, et al. Worldwide experience in newborn screening for classical adrenal hyperplasia due to 21 - hydroxylase deficiency. Pediatr 1988;81:866-74.

6 Cicognani A. The experience of neonatal screening for congenital adrenal hyperplasia. Horm Res 1992;37(suppl 3):34-8. 7 Cutfield WS, Webster D. Newborn screening for congenital 1995;126:118-21.

8 Sack J, Front H, Kaiserman, et al. 21-hydroxylase deficiency: Screening and incidence in Israel. Horm Res 1997;48:115-19.

9 Wallace AM, Beastall GH, Cook B, et al. Neonatal screening for congenital adrenal hyperplasia: a programme based on a novel direct radioimmunoassay for 171986;108:299-308.

10 Larsson A, Hagenfeldt L, Von Dobelin U, Curstedt T, Gustafson J, Svensson E. Neonatal screening for congenital adrenal hyperplasia using 17-hydroxyprogesterone assay in filter paper blood spots. Horm Res 1988;30:235-40.
11 Lee MM, Rajagopalan L, Berg GJ, Moshang T. Serum adrenal steroid concentrations in premature infants. $\mathcal{F}$ Clin Endocrinol Metab 1989;69:1133-6.

12 Berry J, Betts P, Wood PJ. The interpretation of blood spot $17 \alpha$ hydroxyprogesterone levels in term and preterm neonates. Ann Clin Biochem 1986;23:546-51.

13 Ohkubo S, Shimozawa K, Matsumoto M, Kitagawa T. Analysis of blood spot $17 \alpha$ hydroxyprogesterone concentration in premature infants proposal for cut-off limits in screening for congenital adrenal hyperplasia. Acta Paediatr 尹pn 1992;34:126-33.

14 Dixon WJ, ed. BMDP Statistical software. Berkeley: University of California Press, 1990.

15 Allen BA, Hoffman GL, Fitzpatrick P, Laessig R, Maby S, Slyper A. Improved precision of newborn screening for congenital adrenal hyperplasia using weight-adjusted criteria for 17- hydroxyprogesterone levels. I Pediatr 1997;130:128-33.

16 Cacciari E, Balsamo A, Cassio A, et al. Neonatal screening for congenital hyperplasia. Arch Dis Child 1983;58:803-6.

17 Knudtzon J, Markestad T, Aakvaag A, Bergsjo P. Elevated 17 hydroxyprogesterone levels in premature infants.Acta 17 hydroxyprogesterone leve

18 Hingre RV, Gross SJ, Hingre KS, Mayes DM, Richman RA. Adrenal steroidogeneis in very low birth weight preterm infants. F Clin Endocrinol Metab 1994;78:266-70. 